\title{
Human congenital T-cell receptor disorders
}

\author{
Ana V.M. Marin*, Beatriz Garcillán*, Anaïs Jiménez-Reinoso*, Miguel Muñoz-Ruiz, \\ Alejandro C. Briones, Edgar Fernández-Malavé, Maria J. Recio, and José R. \\ Regueiro
}

\begin{abstract}
Immunodeficiencies of most T-cell receptor (TCR) components (TCRID) have been reported in almost 40 patients worldwide who have also, at times, shown signs of autoimmunity. We updated their clinical, immunological, and molecular features with an emphasis on practical diagnosis, as the range of the disorder grows in complexity with new partial defects. Cellular and animal models are also reviewed and in some cases reveal their limitations for predicting TCRID immunopathology.
\end{abstract}

\section{Introduction}

\section{T-cell receptors (TCR)}

Mature T lymphocytes detect antigens with a variable surface TCR heterodimer, which is either $\alpha \beta$ or $\gamma \delta$ (Figure 1).

During early T-cell development, the invariant preT $\alpha$ chain is used instead of TCR $\alpha$. In humans, the variable TCR heterodimers form a complex with 2 invariant heterodimers termed $\mathrm{CD} 3 \gamma \varepsilon$ and $\mathrm{CD} 3 \delta \varepsilon$ and a single invariant homodimer termed $\zeta$ or CD247 (Call et al. 2002). These 3 invariant dimers participate in assembly and surface expression of the whole TCR-CD3-CD247 complex, which we will refer to here as TCR. When a TCR interacts with its specific antigen through the variable heterodimers, intracellular signals are transduced to drive T-cell maturation or apoptosis in the thymus and T-cell activation, proliferation, and effector function or anergy-apoptosis in the periphery (Brownlie and
Zamoyska 2013). The cytoplasmic tails of CD3e and CD247 then expose their ITAM sequences (Love and Hayes 2010), which are phosphorylated by Lck, thus allowing the recruitment and Lck-mediated activation of ZAP-70. Activated ZAP-70 phosphorylates LAT, which recruits numerous signaling molecules to form a multiprotein complex termed the LAT signalosome. This signalosome, in turn, propagates signals to 3 major signaling pathways, namely MAPK, PI3K/AKT, and PLC $\gamma$-1, leading to the activation of transcription factors that are critical for gene expression and essential for T-cell growth and differentiation. Signals initiated from the TCR also result in actin reorganization and the activation of integrins by inside-out signaling (Kuhns and Davis 2012). Most $\alpha \beta$ TCR-bearing T cells recognize processed peptides associated with major histocompatibility complex (MHC) molecules, whereas $\gamma \delta \mathrm{TCR}$ bearing $\mathrm{T}$ cells can respond to a wide variety of antigens irrespective of their molecular nature including peptide and nonpeptide antigens, MHC-related proteins, phosphoantigens, and soluble proteins (Chien et al. 2014).
Department of Immunology, Complutense University School of Medicine, and Hospital 12 de Octubre Health Research Institute, Madrid, Spain.

*Joint first authors.

${ }^{\dagger}$ Corresponding author: José R. Regueiro/regueiro@ucm.es.
Submitted 27 August 2014

Accepted 28 October 2014

Available online 29 October 2014

LymphoSign Journal 2:3-19 (2015) dx.doi.org/10.14785/lpsn-2014-0012 

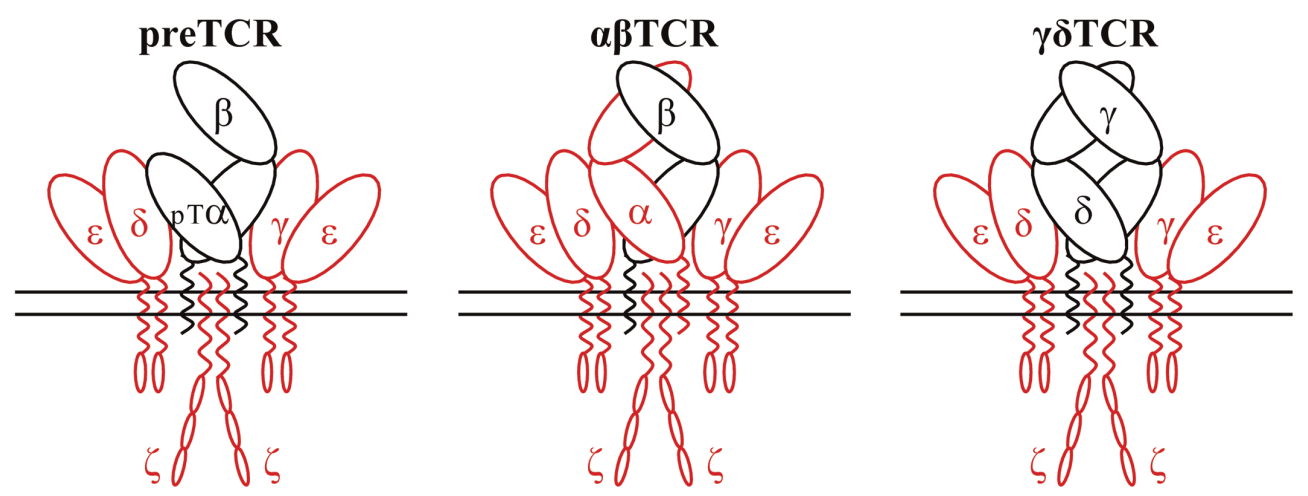

Figure 1: TCR isotypes. Red chains show mutations reported to cause immunodeficiency and (or) autoimmunity (Table 1).

\section{T-cell receptor immunodeficiencies (TCRID)}

TCRIDs are low-prevalence autosomal recessive diseases characterized by impaired surface TCR expression, frequently associated with peripheral blood $\mathrm{T}$ lymphocytopenia, severe combined ID (SCID) and (or) autoimmune symptoms, but not associated with $\mathrm{B}$ or natural killer (NK) lymphocytopenia. The first TCRID was a human familial CD3 expression deficiency in a child with SCID and in his healthy sibling (Regueiro et al. 1986), later shown to be due to a complete CD3 $\gamma$ deficiency (Arnaiz-Villena et al. 1992). A second TCRID was soon reported (Thoenes et al. 1992) and shown to be due to partial CD3e deficiency (Soudais et al. 1993). Several CD3, CD247, and TCR deficiencies have since been described (Figure 1, Table 1), which can be classified as complete or partial according to the absence or presence of residual levels of the affected protein. Although rare and sometimes based on single cases, TCRID offer rich information about the underpinnings of human TCR structure and function, which in turn impact our understanding of T-cell development and function. Therefore we, as have others (Casanova et al. 2014), believe they merit a detailed study.

\section{Clinical and pathological manifestations}

\section{TCRID}

Most patients show SCID or CID features such as recurrent respiratory infections, otitis, candidiasis, diarrhea, failure to thrive, and sometimes autoimmune phenomena in the first year of life. Thymus size can be small (CD $3 \gamma, \delta$, or $\varepsilon$ deficiency (Arnaiz-Villena et al. 1991; de Saint Basile et al. 2004; Takada et al. 2005)) or normal (CD3 $\gamma$ or CD247 deficiency, unpublished). Chronic pyogenic infections, dysmorphic features, or bone abnormalities were not reported. Stem cell transplantation is indispensable when SCID is present, otherwise most patients die early in life as a consequence of viral infection (cytomegalovirus mainly, but also adenovirus). Autoimmune phenomena have been described in several patients, mainly when $\mathrm{T}$ cells are present. Most CD3 $\gamma$-deficient patients showed autoimmune hemolytic anemia (AHA) or vitiligo (Arnaiz-Villena et al. 1992) and also autoimmune thyroiditis, thrombocytopenia, or autoimmune hepatitis (Gokturk et al. 2014). Two

Table 1: TCR immunodeficiencies.

\begin{tabular}{|c|c|c|c|c|}
\hline \multirow[b]{2}{*}{ Protein } & \multicolumn{2}{|l|}{ References } & \multicolumn{2}{|c|}{ Number of cases } \\
\hline & Complete & Partial & Families & Patients \\
\hline CD3 $\gamma$ & $\begin{array}{l}\text { Arnaiz-Villena et al. 1992; Sanal et al. 1996; Allende } \\
\text { et al. 2000; Recio et al. 2007; Ozgur et al. 2008; } \\
\text { Tokgoz et al. 2013; Gokturk et al. } 2014\end{array}$ & - & 5 & 10 \\
\hline CD3 $\delta$ & $\begin{array}{l}\text { Dadi et al. 2003; de Saint Basile et al. 2004; Takada } \\
\text { et al. 2005; Marcus et al. } 2011\end{array}$ & $\begin{array}{l}\text { Gil et al. 2011; de la Calle-Martín, } \\
\text { unpublished data }\end{array}$ & 10 & 19 \\
\hline $\mathrm{CD} 3 \varepsilon$ & de Saint Basile et al. 2004; Fuehrer et al. 2014 & Soudais et al. 1993 & 3 & 5 \\
\hline$\zeta$ or CD247 & $\begin{array}{l}\text { Rieux-Laucat et al. 2006; Roberts et al. 2007; Marin, } \\
\text { unpublished data }\end{array}$ & & 3 & 3 \\
\hline $\mathrm{TCR} \alpha$ & Morgan et al. 2011 & & 2 & 2 \\
\hline Total & & & 23 & 39 \\
\hline
\end{tabular}


TCR $\alpha$-deficient patients presented with vitiligo, AHA, or autoantibodies (Morgan et al. 2011). These results indicate that both positive selection and negative selection, which are TCR-dependent events, can be impaired in TCRID.

\section{The CD3 $\gamma$ deficiency exception}

In contrast with all other reported TCRID due to complete protein deficiencies (Table 1), most CD3 $\gamma$ deficient individuals reported to date (7 out of 10$)$ are presently alive and well without transplantation (Table 2), including some in their thirties. Late diagnosis, mild $\mathrm{T}$ lymphopenia, low TCR expression, and autoimmune features are common (see "TCRID" section). These limited immunological consequences are at odds with what is observed when the very homologous $\mathrm{CD} 3 \delta$ chain is absent: early diagnosis, severe T lymphopenia, no TCR expression, and urgent transplantation. This clearly shows that CD $3 \gamma$ is not critical for survival in most cases, as compared with other TCR proteins, and particularly with $\mathrm{CD} 3 \delta$. The most likely molecular explanation is that $\mathrm{CD} 3 \delta$ can replace $\mathrm{CD} 3 \gamma$ in the TCR, as has been reported (Zapata et al. 2004), whereas the reverse is not possible. As we review in the "Animal models" section, this is not the case in CD3 $\gamma$ Knock-Out (KO) mice. However, 3 out of $10 \mathrm{CD} 3 \gamma$-deficient patients, even though they had received transplants, did not survive to adulthood, thus suggesting that therapeutic decisions must be taken on a case by case basis.

\section{Diagnosis}

\section{Differential diagnosis}

A male or female infant showing $\mathrm{T}$ lymphopenia could be a result of TCRID, but also of mutations in IL7R $\alpha$, FOXN1, Coronin-1A, Zap70, TAP, MHC class II, transcription factors, PNP, ADA, or 22q11.2 (DiGeorge syndrome) (Al-Herz et al. 2014); however, only TCRID show TCR expression defects when T cells are present. Thus, a careful flow cytometry study is essential for the early differential diagnosis of TCRID, which is critical for patient survival, and should include both $\alpha \beta$ and $\gamma \delta$ T-cell subsets.

\section{Sample quality}

Samples are often received from abroad and travel long distances at changing temperatures before they reach the diagnostic lab. In such cases it is important to include age-matched controls that suffer similar shortcomings, so that comparisons can be meaningful.

\section{T-cell subset definition and lymphopenia}

TCRID may have no $\mathrm{T}$ cells and are thus properly called $\mathrm{T}^{-} \mathrm{B}^{+} \mathrm{NK}^{+}$. But often some $\mathrm{T}$ cells are present $\left(\mathrm{T}^{ \pm} \mathrm{B}^{+} \mathrm{NK}^{+}\right)$, although their identification using $\mathrm{CD} 3$ as an extracellular marker can be difficult owing to their reduced TCR expression. Indeed, some authors have reported $\mathrm{T}^{-} \mathrm{B}^{+} \mathrm{NK}^{+}$phenotypes despite the presence of abundant $\mathrm{CD}^{+}$and $\mathrm{CD}^{+}$lymphocytes expressing very low levels of surface CD3 (Roberts et al. 2007). As intracellular CD3 is not normally used for screening TCRID, we used extracellular CD4 and CD8 to identify $\mathrm{T}$ cells in TCRID patients. We have shown that essentially all $\mathrm{CD}^{+}$and $\mathrm{CD} 8^{\text {bright }}$ cells within the lymphocyte gate are $\alpha \beta$ T cells and, conversely, most double negative cells (DN, $\left.\mathrm{CD}^{-} \mathrm{CD} 8^{-}\right)$in the same gate are $\gamma \delta \mathrm{T}$ cells (Muñoz-Ruiz et al. 2013). CD8 ${ }^{\text {dull }}$ lymphocytes are mostly NK cells. For comparative purposes, we have considered $\mathrm{CD}^{+}$lymphocytes in Table 2 because they are widely reported, although it is likely an underestimation of the true number of $\mathrm{T}$ cells. Chimerism should be excluded using standard fingerprinting procedures, to avoid for instance counting the mother's T cells, as reported recently in a new case of CD3e deficiency (Fuehrer et al. 2014).

Using these criteria, most patients with complete defects show selective peripheral blood $\mathrm{T}$ lymphopenia, either $\mathrm{T}^{-} \mathrm{B}^{+} \mathrm{NK}^{+}$or $\mathrm{T}^{ \pm} \mathrm{B}^{+} \mathrm{NK}^{+}$depending on the affected TCR chain, which is a first clue to the molecular basis of the pathology. $\mathrm{T}^{-} \mathrm{B}^{+} \mathrm{NK}^{+}$has been associated with complete $\mathrm{CD} 3 \varepsilon$ or $\mathrm{CD} 3 \delta$ defects, with less than $2 \%$ peripheral blood $\mathrm{T}$ cells. $\mathrm{T}^{ \pm} \mathrm{B}^{+} \mathrm{NK}^{+}$has been reported in complete CD $3 \gamma$, TCR $\alpha$, or CD247 defects. All partial TCRID show a $\mathrm{T}^{ \pm} \mathrm{B}^{+} \mathrm{NK}^{+}$or even a $\mathrm{T}^{+} \mathrm{B}^{+} \mathrm{NK}^{+}$immunophenotype.

TCRID are best diagnosed if both $\alpha \beta$ and $\gamma \delta$ T cells are studied, as shown for complete TCR $\alpha$ deficiency (Morgan et al. 2011) and for partial CD3 $\delta$ deficiency (Gil et al. 2011), both of which shared a $T \alpha \beta^{-} \gamma \delta^{+} \mathrm{B}^{+} \mathrm{NK}^{+}$ immunophenotype despite their disparate molecular basis. Figure 2 (top) summarizes the effects of TCRID mutations in T-cell development.

\section{Surface TCR expression in patients' lymphocytes}

We have listed the monoclonal antibodies used in our lab for surface staining of peripheral blood lymphocytes from possible TCRID patients (Table 3, extracellular). 


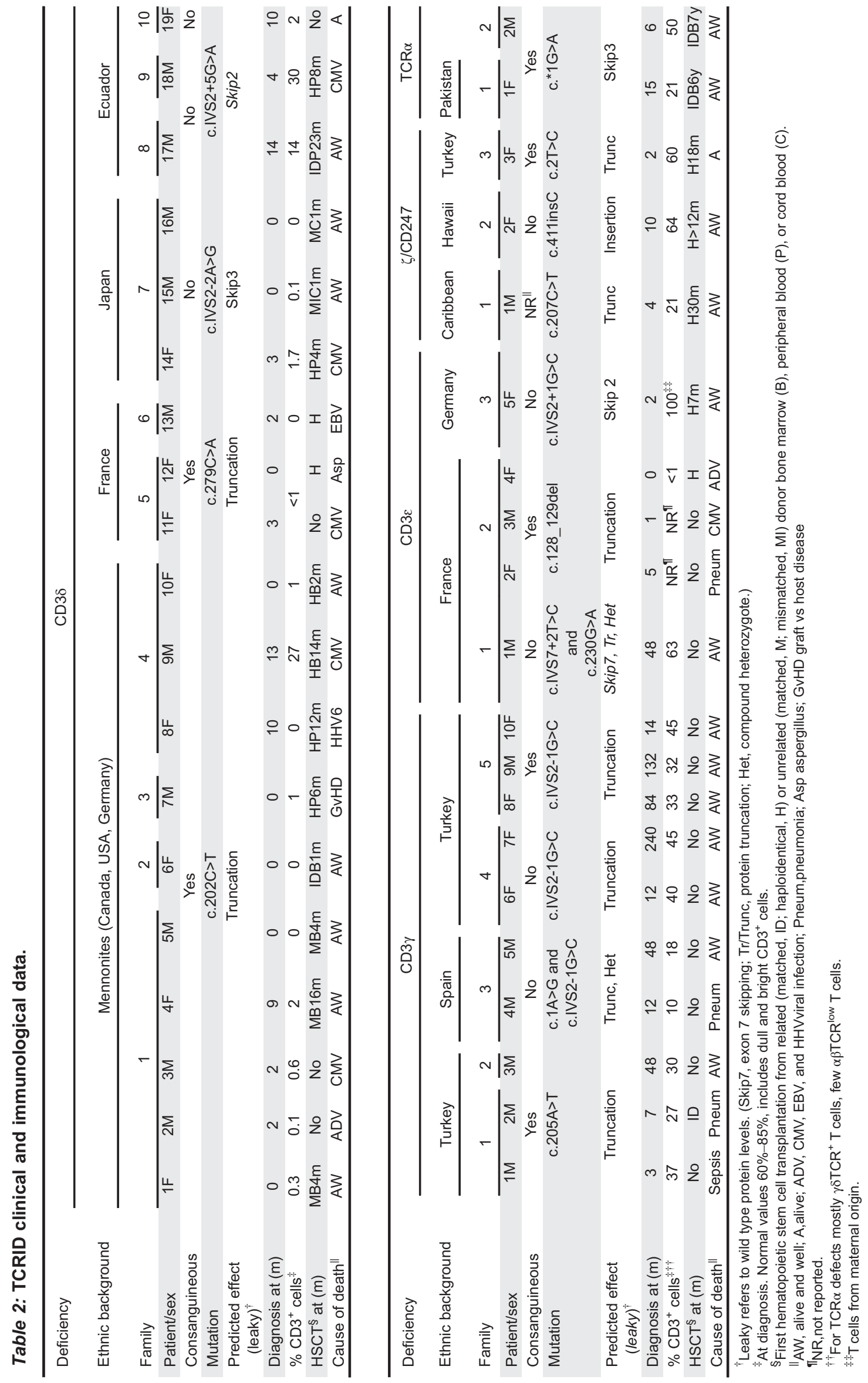




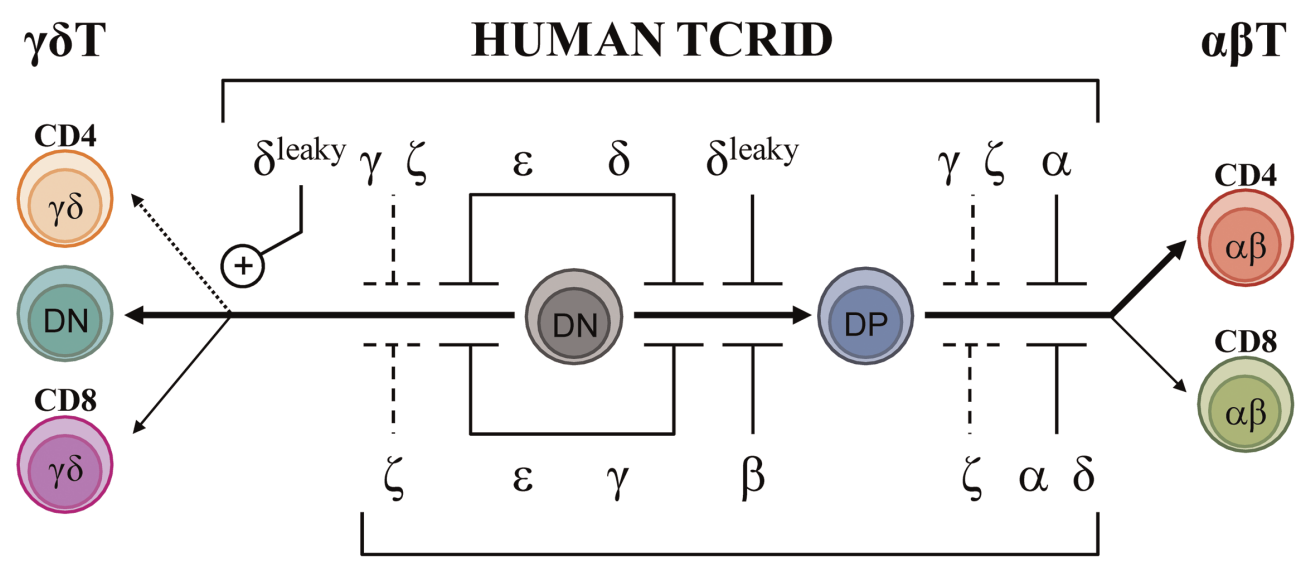

MOUSE KO

Figure 2: Impact of mutations causing complete TCRID on human $\alpha \beta$ (right) and $\gamma \delta$ (left) T-cell development (top), as compared with knock-out (KO) mice (bottom). Isolated Greek letters except $\alpha$ and $\beta$ stand for invariant CD3 or CD247 chains, all other are variable TCR chains. (DN, double negative $\left(C D 4^{-} C D 8^{-}\right)$; $D P$, double positive $\left.\left(C D 4^{+} C D 8^{+}\right)\right)$.

We start with just UCHT-1 (anti-CD3e), 11F2 (anti$\gamma \delta \mathrm{TCR})$, and any anti-CD4 and anti-CD8 $\alpha$ antibodies, and in a different staining IP26 (anti- $\alpha \beta$ TCR) and $11 \mathrm{~F} 2$ (anti- $\gamma \delta \mathrm{TCR}$ ). Within a subset (for instance, CD4 ${ }^{+}$lymphocytes), TCR Mean Fluorescence Intensity is evaluated with any of those CD3- or TCR-specific antibodies in comparison with that of an age-matched healthy control (Figure 3, top center). The expression of CD4 itself can serve as an internal control (Figure 3, top left). We normally use a range of CD3specific monoclonal antibodies, such as those listed in Table 3 (extracellular), to confirm any TCR expression defect.

Table 3: Monoclonal antibodies used for TCRID diagnosis.

\begin{tabular}{|c|c|c|c|}
\hline Specifity & Name & Species & Source \\
\hline \multicolumn{4}{|c|}{ Extracellular } \\
\hline$\alpha \beta$ TCR & IP26 & Mouse & Biolegend \\
\hline$\alpha \beta$ TCR & BMA031 & Mouse & Miltenyi Biotec \\
\hline$\alpha \beta$ TCR & WT31 & Mouse & BD Biosciences \\
\hline$\gamma \delta \mathrm{TCR}$ & $11 \mathrm{~F} 2$ & Mouse & BD Biosciences \\
\hline$\gamma \delta \mathrm{TCR}$ & Inmu510 & Mouse & Beckman Coulter \\
\hline $\mathrm{CD} 3 \varepsilon$ & Leu-4 & Mouse & Beckton Dickinson \\
\hline $\mathrm{CD} 3 \varepsilon$ & S4.1 & Mouse & Invitrogen \\
\hline $\mathrm{CD} 3 \varepsilon$ & UCHT-1 & Mouse & Beckman Coulter \\
\hline \multicolumn{4}{|c|}{ Intracellular } \\
\hline $\mathrm{CD} 3 \varepsilon$ & UCHT-1 & Mouse & Beckman Coulter \\
\hline CD38 & EP4426 & Rabbit & Abcam \\
\hline CD3 $\gamma$ & EPR4517 & Rabbit & Abcam \\
\hline$\zeta / C D 247$ & 6B10.2 & Mouse & Biolegend \\
\hline TCR $\beta$ & Jovi-1 & Mouse & Non commercial \\
\hline $\mathrm{TCR} \beta$ & $\beta \mathrm{F} 1$ & Mouse & Non commercial \\
\hline
\end{tabular}

Family members are not appropriate controls, because in some cases they also show (partial) TCR expression defects that may underestimate the patient's defect (see Figure 3 and Muñoz-Ruiz et al. 2013, top center and "Surface TCR expression in carriers' lymphocytes"). If no TCR expression defect is observed, TCRID can be excluded. If a TCR expression defect is ascertained, both $\alpha \beta$ and $\gamma \delta$ T cells should be analyzed. If $\alpha \beta$ T cells (defined as $\mathrm{CD}^{+}$and (or) $\mathrm{CD} 8^{\text {bright }}$ ) show impaired TCR expression and $\gamma \delta \mathrm{TCR}^{+}$show normal surface TCR expression, TCR $\alpha$ deficiency is likely. If $\alpha \beta$ and $\gamma \delta$ T cells share a surface TCR expression defect, a CD3 or CD247 defect may be suspected and further studies are required to identify the culprit protein (see "Protein identification in patients' lymphocytes"), as indicated in the diagnostic flow chart (Figure 3, bottom). The following TCR expression hierarchy may be useful for the diagnosis of TCRID due to the lack of the indicated chains: $\mathrm{CD} 3 \varepsilon=\mathrm{CD} 3 \delta=\mathrm{TCR} \alpha \geq \mathrm{CD} 247>\mathrm{CD} 3 \gamma$ (our experience). Also, studying NK cells can be informative, as CD247 deficiency affects the expression of NK surface receptors such as CD16 or NKp30 (Reyburn, unpublished data). It is important to note that in contrast to $\alpha \beta$ T cells, the range of surface TCR levels in $\gamma \delta$ T cells in different individuals is quite heterogeneous (Garcillán et al. 2014), a fact that must be taken into account when analyzing the overlays of $\gamma \delta$ T cells.

Lastly, it is advisable to grow T cells using IL-2 plus allogeneic feeder cells or immortalize them with Herpesvirus saimiri (HVS) or Human T-cell leukemia virus type 1 (HTLV-1), (see "Functional studies" and "Cellular models"), so that the detected TCR expression defects can be ascertained and further analyzed. 

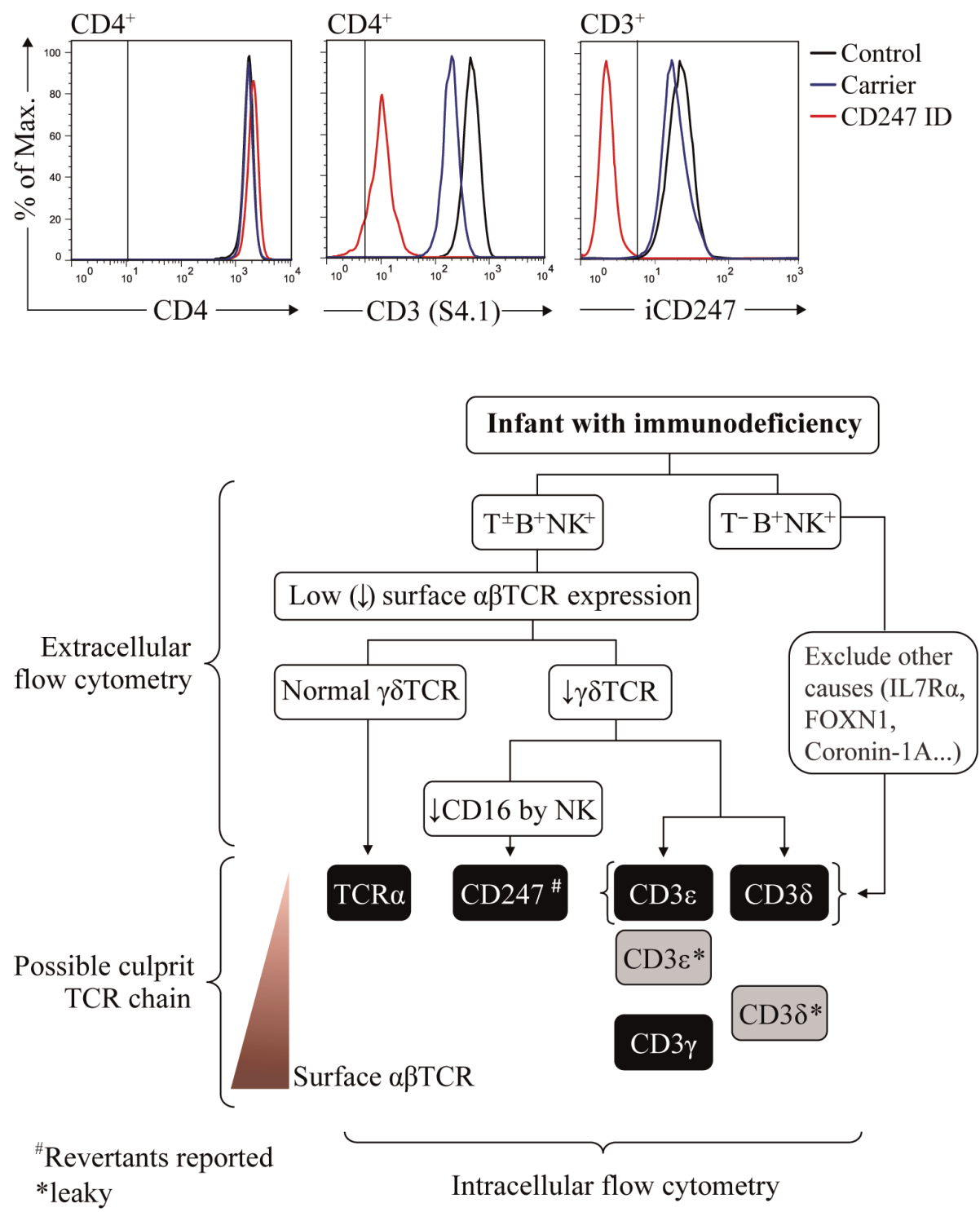

Figure 3: TCRID diagnosis by flow cytometry. Top: example of histogram overlays of a control, a carrier and a CD247 deficiency patient (black, blue, and red line, respectively) using extracellular (left and center) and intracellular (right) staining with the indicated antibodies and gates. Vertical lines are the isotype control fluorescence upper limit. Bottom: diagnostic flow chart using cytometric data. Keys represent expected defects, as $\alpha \beta T C R$ expression values were not available in these TCRID.

\section{Surface TCR expression in carriers' lymphocytes}

The detection of TCRID mutation carriers using flow cytometry is difficult because surface TCR expression is often within the normal range. Again, overlays of extracellular CD3e staining can be used to compare several family members, as shown in Figure 3 (top center), for CD247 (Marin and Garcillán, unpublished data). Using similar strategies, we have shown that $\mathrm{CD} 3 \gamma^{+-}, \mathrm{CD}^{+/-}$(and even $\mathrm{CD} 3 \delta^{+/ \text {leaky }}$ ) carriers can be identified, although the difference is not so clear and can be confounded by normal surface TCR variation (Muñoz-Ruiz et al. 2013). Of course, a genetic analysis is required for confirmation.

\section{Protein identification in patients' lymphocytes}

In the past, immunoprecipitation (Perez-Aciego et al. 1991) or Western blot techniques (Gil et al. 2011) had to be used for the identification of protein defects. But these approaches require large amounts of $\mathrm{T}$ cells, which are difficult to obtain when samples are scarce (as is 
Table 4: Mutations found in TCRID.

\begin{tabular}{|c|c|c|c|c|c|}
\hline Mutation & LOCUS & Site & Sequence variation & Expression & References \\
\hline \multicolumn{6}{|l|}{ I. Missense } \\
\hline p.M1T & $C D 247$ & exon 1 & c. $2 \mathrm{~T}>\mathrm{C}$ & $\begin{array}{l}\text { CD247 WT detected in revertant } \\
\text { T cells (lower TCR/CD3 expression } \\
\text { levels, only for compensatory } \\
\text { mutant) }\end{array}$ & (Marin, unpublished) \\
\hline p.M1V & $C D 3 G$ & exon 1 & c. $1 A>G$ & ND & $\begin{array}{l}\text { (Arnaiz-Villena } \\
\text { et al. 1992) }\end{array}$ \\
\hline \multicolumn{6}{|l|}{ II. Nonsense } \\
\hline p.W59X & $C D 3 E$ & exon 6 & c. $230 \mathrm{G}>\mathrm{A}$ & NR & (Soudais et al. 1993) \\
\hline p.Q70X & $C D 247$ & exon 3 & c. $207 \mathrm{~T}>\mathrm{C}$ & $\begin{array}{l}\text { CD247 WT detected in revertant } \\
\text { T cells (normal TCR/CD3 } \\
\text { expression levels) }\end{array}$ & $\begin{array}{l}\text { (Rieux-Laucat } \\
\text { et al. 2006) }\end{array}$ \\
\hline p.K69X & $C D 3 G$ & exon 3 & c. $205 \mathrm{~A}>\mathrm{T}$ & ND & (Recio et al. 2007) \\
\hline p.R68X & $C D 3 D$ & exon 2 & c. $202 \mathrm{C}>\mathrm{T}$ & $\begin{array}{l}\text { Truncated CD3 } 3 \text { protein was not } \\
\text { detected }\end{array}$ & $\begin{array}{l}\text { (de Saint Basile et al. } \\
\text { 2004), (Dadi 2003) }\end{array}$ \\
\hline p.C93X & $C D 3 D$ & exon 2 & c. $279 \mathrm{C}>\mathrm{A}$ & NR & $\begin{array}{l}\text { (de Saint Basile } \\
\text { et al. 2004) }\end{array}$ \\
\hline \multicolumn{6}{|l|}{ III. Splice-site } \\
\hline Deletes exon 2 & $C D 3 E$ & intron 2 & c.IVS2+1G>C & $\begin{array}{l}\text { Mutant CD } 3 \varepsilon \text { protein was not } \\
\text { detected (Kozak consensus } \\
\text { sequence at position } 82 \text { in exon } 4 \\
\text { could not be used as alternative } \\
\text { stop codon) }\end{array}$ & (Fuehrer et al. 2014) \\
\hline Deletes exon 7 & CD3E & intron 7 & c.IVS7+2T>C & $\begin{array}{l}\text { Mutant CD3c protein was not } \\
\text { detected }\end{array}$ & (Soudais et al. 1993) \\
\hline $\begin{array}{l}\text { Cryptic splice } \\
\text { site }\end{array}$ & $C D 3 G$ & intron 2 & c.IVS2-1G>C & ND & $\begin{array}{l}\text { (Arnaiz-Villena et al. } \\
\text { 1992, Tokgoz et al. } \\
\text { 2013, Gokturk } \\
\text { et al. 2014) }\end{array}$ \\
\hline Deletes exon 3 & $C D 3 D$ & intron 2 & c. IVS2-2A>G & $\begin{array}{l}\text { Truncated CD38 protein was not } \\
\text { detected }\end{array}$ & (Takada et al. 2005) \\
\hline Deletes exon 2 & $C D 3 D$ & intron 2 & c.IVS2+5G>A & $\begin{array}{l}\text { Truncated CD3 } 8 \text { protein was } \\
\text { detected in transfected HeLa cells } \\
\text { but not in PBMC from patients }\end{array}$ & (Gil et al. 2011) \\
\hline $\begin{array}{l}\text { Deletes exon 3/ } \\
\text { p.T107fs X56 }\end{array}$ & TCRA & exon 3 & c. ${ }^{*} 1 G>A$ & $\begin{array}{l}\text { Reduced levels of TCR } \alpha \text { and TCR } \beta \\
\text { expression/ no colocalization }\end{array}$ & (Morgan et al. 2011) \\
\hline \multicolumn{6}{|c|}{ IV. Deletions/insertions } \\
\hline p. T43fsX56 & $C D 3 E$ & exon 6 & c.128_129del & NR & $\begin{array}{l}\text { (de Saint Basile } \\
\text { et al. 2004) }\end{array}$ \\
\hline p. D138fsX272 & $C D 247$ & exon 7 & c. 411 ins C & CD247 protein was not detected & (Roberts 2007) \\
\hline
\end{tabular}

'Reversions reported.

ND, not done; NR, not reported

often the case with infant patients), and even more difficult in cases with severe T-cell lymphopenia. Generation of T-cell lines can be a solution, but they take precious time, thereby delaying diagnosis. CD3 chainspecific antibodies for intracellular staining have become available lately, and in our hands simplified the diagnosis of TCRID, which can now be done rapidly. Table 3 (intracellular) lists such antibodies and Figure 3 (top right) shows a recent example of their use. Once the culprit protein is defined, genetic validation is indispensable to establish the molecular basis of the protein defect.
In summary, excellent reagents are now available to diagnose TCRID defects in a record time, even when very few $\mathrm{T}$ cells are present.

\section{Mutation analysis}

A mutation database has been established that contains most described mutations in the genes encoding for TCR chains (Piirilä et al. 2006). Mutations causing TCRID include missense, nonsense, and splice-site mutations as well as less common genomic deletions and insertions (Table 4). Figure 4 illustrates their 


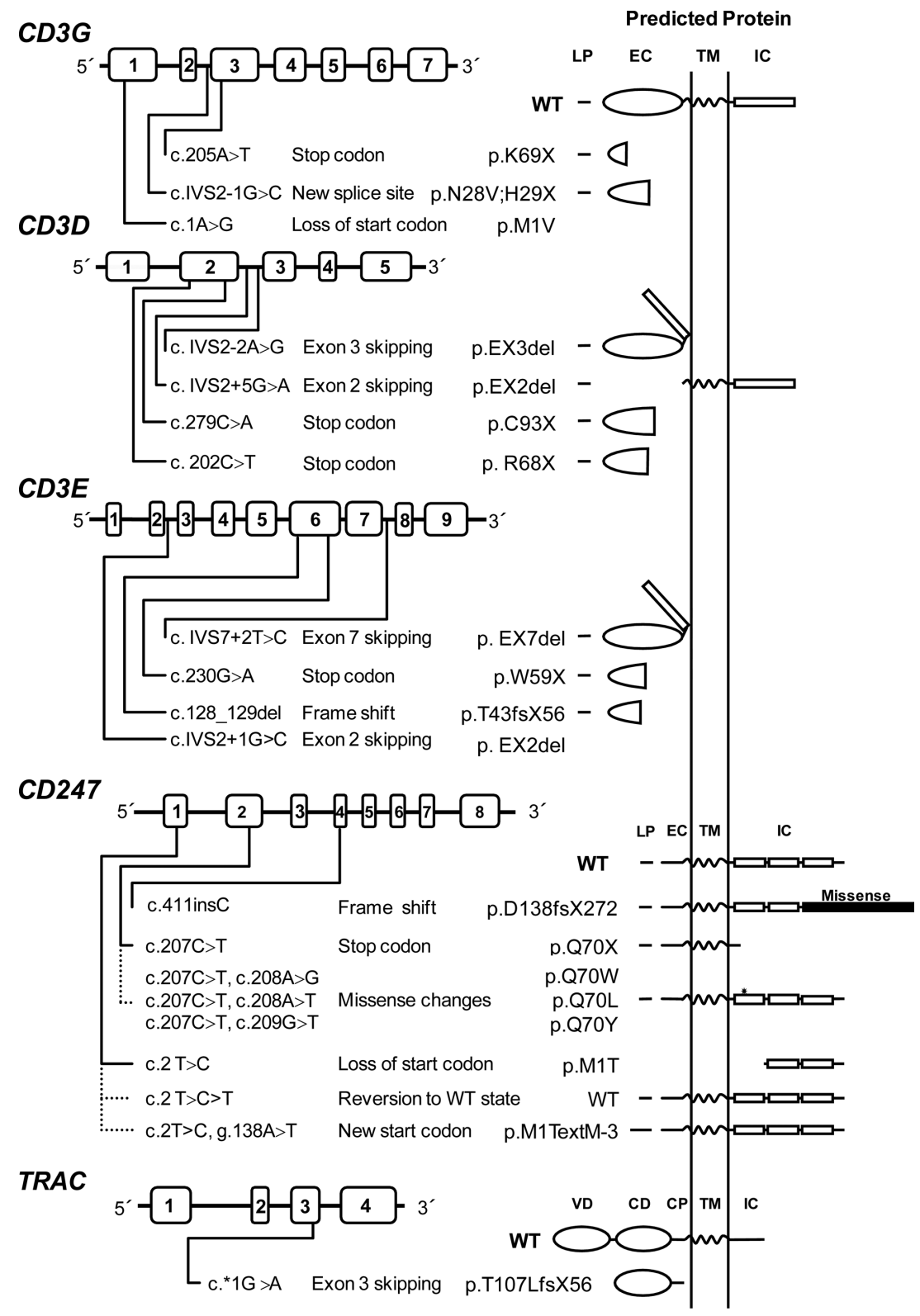

Figure 4: Graphical representation of mutations causing TCRID and their predicted protein products, including reversions (dotted lines). (LP, leader peptide; EC, extracellular; TM, transmembrane; IC, intracellular; VD, variable domain; $\mathrm{CD}$, constant domain; $\mathrm{CP}$, connecting peptide.)

presumed protein products that, when truncated, are often unstable.

Most mutations drastically affect the expression of the protein (complete defects), whereas in some leaky splice-site mutations, small amounts of normal transcripts were produced, allowing for the expression of some normal protein and thus causing a partial phenotype. This is the case for CD $3 \delta$ and CD $3 \varepsilon$ TCRID.

Potentially truncated proteins have also been reported and were likely unstable, as they were undetectable in
$\mathrm{T}$ cells. Indeed, the in-frame deletion of exon 7 predicted a mutant $\mathrm{CD} 3 \varepsilon$ protein that was not found even with very sensitive techniques (Thoenes et al. 1992). Also, a predicted mutant $\mathrm{CD} 3 \delta$ protein selectively lacking the extracellular domain encoded by exon 2 was undetectable in peripheral blood mononuclear cells (PBMC) from the patient or carriers, although it could be shown in transfected non-T cells (Gil et al. 2011). This may be mutation specific, as shown recently in a new splicing mutation in $C D 3 E$ intron 2, which was predicted to delete exon 2 and thus the start codon. As a consequence, no protein was detected by Western blot 
either in carrier PBMC or in transfected non-T cells (Fuehrer et al. 2014). In TCR $\alpha$ deficiency, a c. ${ }^{\star} 1 \mathrm{G}>\mathrm{A}$ mutation resulted in an aberrant transcript joining exon 2 to the normally untranslated exon 4 . In the predicted translation product, the 35 C-terminal amino acids would be replaced by 56 amino acids encoded by exon 4. This would result in partial loss of the connecting peptide domain and abolition of the transmembrane and cytoplasmic domains of the TCR $\alpha$ chain. In PBMC, no TCR $\alpha$ or TCR $\beta$ proteins were detected by Western blotting with specific antibodies, but minute amounts of both chains were detectable by immunofluorescence microscopy using a different set of antibodies. The authors concluded that the residual predicted truncated TCR $\alpha$ failed to bind normally to TCR $\beta$, because in the latter experiment the TCR chains did not colocalize. This was later confirmed in transfected HeLa cells (Morgan et al. 2011).

Nonsense mutations are clearly deleterious and frequently associate with severe TCRID immunophenotypes, except for complete $\mathrm{CD} 3 \gamma$ and partial $\mathrm{CD} 3 \varepsilon$ deficiencies. In $\mathrm{CD} 3 \delta$ deficiency, a microarray analysis in thymocytes revealed more than 2-fold lower specific transcripts, but no CD3 $\delta$ protein was detected by Western blot analysis of the same lysates or by thymus immunohistochemistry (Dadi et al. 2003).

Somatic mosaicism caused by reversions can ease otherwise severe clinical phenotypes. Reversions have been reported in several disorders, including dermatological, metabolic, and immunological disorders such as ADA deficiency, X-linked SCID, and Wiskott-Aldrich syndrome (Hirschhorn 2003; Wada and Candotti 2008).

Reversion of some T cells to carrier TCR expression levels has been shown to be the consequence of CD247 germ-line mutations when studied (Figure 4). However, TCR signaling after stimulation with phytohemagglutinin (PHA) or anti-CD3 of revertant $\mathrm{T}$ cells can be impaired (Rieux-Laucat et al. 2006) or restored to carrier levels (Marin, unpublished data) for reasons yet to be defined. Interestingly, no reversions have been reported in other TCRID, suggesting that CD247 is more prone to somatic mutations than the $C D 3$ or TRAC genes.

$C D 3 G D E$ haplotype analysis using polymorphic markers can be useful (i) to rule out CD3 mutations, if segregation does not fit the pedigree; (ii) to establish the existence of founder alleles even when families are unaware of such connections, as we have reported for $C D 3 G$ in Turkey (Recio et al. 2007) and for CD3D in Ecuador (Gil et al. 2011); and (iii) for carrier detection and (or) prenatal diagnosis, because recombination within the $C D 3$ gene complex is rare.

Screening tests specific for some founder $C D 3 G$ and CD3D mutations using TaqI and BsaAI (Table 5) have been developed for several Turkish and Ecuadorian families, respectively, which help to reach quick diagnoses and segregation data for genetic counselling (Recio et al. 2007; Gil et al. 2011). Therefore, in Turkish or Ecuadorian patients with an immunophenotype suggestive of $\mathrm{CD} 3 \gamma$ or $\mathrm{CD} 3 \delta$ deficiency, regardless of the accompanying spectrum of clinical symptoms, screening for such mutations should be considered in their molecular diagnosis.

\section{Functional studies}

T-cell functional analyses both in vivo and in vitro are useful, but not critical, for TCRID diagnosis, as they are frequently impaired even when $\mathrm{T}$ cells are abundant or in healthy siblings, as reported for $\operatorname{CD} 3 \gamma$ deficiencies (Recio et al. 2007). More often, lymphopenia precludes functional studies in primary $\mathrm{T}$ cells, so it becomes necessary to use immortalized cell lines to explore the functional impact of the mutations in T-cell function. For this purpose, $\mathrm{T}$ cells can be immortalized with HVS or HTLV-1 (Pacheco-Castro et al. 1998).

Table 5: Screening test for carrier detection in CD3 $\gamma$ and CD3 $\delta$ deficiencies.

\begin{tabular}{|c|c|c|c|c|c|c|}
\hline \multirow[b]{2}{*}{ Enzyme } & \multirow{2}{*}{$\begin{array}{l}\text { Restriction } \\
\text { site }\end{array}$} & \multirow{2}{*}{$\begin{array}{c}\text { Mutation / } \\
\text { LOCUS }\end{array}$} & \multirow[b]{2}{*}{ Position } & \multirow[b]{2}{*}{ PCR primers } & \multicolumn{2}{|c|}{ Restriction fragments (bp) } \\
\hline & & & & & Homozygous & Heterozygous \\
\hline Tru9l & TTAA & $\begin{array}{l}\text { c.205A>T / } \\
\text { CD3G }\end{array}$ & exon 3 & $\begin{array}{l}\text { 5'-TGGTATGCAGAAGCAGGGAGAA-3' } \\
\text { 5'-TAAAAAGCTCACCAGAACAGCAAAT-3' }\end{array}$ & 138,37 & $175,138,37^{\dagger}$ \\
\hline BsaAl & TACGTG & $\begin{array}{l}\text { c.IVS2+5G>A / } \\
\text { CD } 3 D\end{array}$ & intron 2 & $\begin{array}{l}\text { 5'-TGAGCTTCCGCAGAACAAAGG-3' } \\
\text { 5'-CACATCCAGAAGCCCTATCCATT-3' }\end{array}$ & 345 & $345,295,50^{\dagger}$ \\
\hline
\end{tabular}

${ }^{\dagger} 37$ and $50 \mathrm{bp}$ fragments were not visible in agarose gel 
Additionally, fresh PBMC can be cultured with allogeneic feeder cells ( $\mathrm{a} \gamma$-irradiated mixture of EBV-transformed lymphoblastoid cells and PBMC from several healthy donors).

TCR-triggered early activation events (such as $\mathrm{Ca}^{2+}$ influx and CD69 or CD25 induction) and late activation events (such as proliferation induced by mitogenic, antigenic, or allogeneic stimuli) sometimes show contradictory results. For instance, $\mathrm{T}$ cells from $\mathrm{CD} 3 \delta^{\text {leaky }}$ patients showed strongly reduced induction of CD69 and CD25 but normal proliferation when anti-CD3 or PHA stimulation were used (Gil et al. 2011). In other cases, although anti-CD3 responses were reduced, costimulation with CD28 or IL-2 restored proliferative responses (Le Deist et al. 1991; Rieux-Laucat et al. 2006).

Thymus function, often measured as output of peripheral blood recent thymic emigrants $\left(\mathrm{CD} 4{ }^{+} \mathrm{CD} 45 \mathrm{RA}^{+} \mathrm{CD} 31^{+}\right.$lymphocytes), is frequently impaired in TCRID. Additionally, TCR diversity is commonly poor, as measured looking at TCRB clonality and TCRV $\beta$ diversity (Gil et al. 2011).

Despite impaired T-cell responses, TCRID are not always associated with diminished B-cell memory subsets, reduced immunoglobulin (Ig) levels, or abnormal vaccination responses, as reported in TCR $\alpha$ deficiency (Morgan et al. 2011) and in CD38 $\delta^{\text {leaky }}$ deficiency (Gil et al. 2011).

\section{Treatment and prognosis}

The only effective treatment is hematopoietic stem cell transplantation (HSCT), and the sooner the better (Marcus et al. 2011). Patients with successful transplants have been shown to be healthy up to 18 years posttransplantation. Otherwise, the prognosis is very poor for those with complete or even some partial defects such as CD3 $\delta^{\text {leaky }}$ (Table 2), with some exceptions (see next paragraph). Matched related, haploidentical mismatched related, matched unrelated, and mismatched unrelated donors have all been used for HSCT, generally after myeloablative conditioning, but matched related donor HSCT is also used without conditioning when SCID is diagnosed. Complete T-cell reconstitution is generally observed (including normalized B cell function), but split-chimerism has been recently reported for $\mathrm{CD} 3 \varepsilon$ deficiency, which 15 years later resulted in the need of intravenous Igs owing to of lack of switched memory B cells (Fuehrer et al. 2014). A diminished switched memory B-cell subset is a common finding in other SCID patients (Sarantopoulos et al. 2009). A frequent complication of HSCT is graft versus host disease, which can be treated with immunosuppression as was done recently in a case with CD247 deficiency (Aydogmus, unpublished data). When autoimmunity is present, immunosuppression is also required (steroids and cyclosporin A), as reported recently for Evans syndrome in CD3 $\gamma$ deficiency (Tokgoz et al. 2013).

Some $\mathrm{CD} 3 \gamma$ - and a partial $\mathrm{CD} 3 \varepsilon$-deficient patient without ID symptoms did not receive HSCT, but rather antibiotics only when symptoms developed (Allende et al. 2000) or prophylactic intravenous Igs with antibiotics (Le Deist et al. 1991), respectively.

\section{Models of TCRID}

\section{Animal models}

Knock-Out (KO) mouse models (Table 6) have been used to replicate human congenital TCRID, because mouse and human TCR and CD3 chains share significant sequence and functional homology (Dave 2009). Indeed, a block in intrathymic T-cell development and reduced TCR expression was reported in all cases, although sharp differences were found for $\mathrm{CD} 3 \gamma$ and CD38 (Figure 2).

$\mathrm{CD} 3 \delta^{-1-}$ mice and humans shared a severe selective $\alpha \beta$ T lymphocytopenia, but this was due to a block at different checkpoints (DP in mice vs DN in humans, Dave 2009). However, although CD38-deficient patients also lacked $\gamma \delta \mathrm{T}$ cells, CD3 $\delta^{-1-}$ mice showed no obvious defect in $\gamma \delta$ T-cell development or TCR expression (Dave et al. 1997). The mechanism became clear when stoichiometry studies showed that in humans, but not in mice, the $\gamma \delta \mathrm{TCR}$ incorporates $\mathrm{CD} 3 \delta$ (Hayes and Love 2006; Siegers et al. 2007).

Table 6: TCRID mouse models.

\begin{tabular}{|c|c|c|}
\hline \multirow[b]{2}{*}{ Protein } & \multicolumn{2}{|c|}{ Reference } \\
\hline & Complete & Partial \\
\hline CD3 $\gamma$ & Haks et al. 1998 & \\
\hline CD38 & Dave et al. 1997 & \\
\hline $\mathrm{CD} 3 \varepsilon$ & $\begin{array}{l}\text { Malissen et al. 1995; } \\
\text { DeJarnette et al. } 1998\end{array}$ & Wang et al. 2009 \\
\hline$\zeta / \mathrm{CD} 247$ & $\begin{array}{l}\text { Malissen et al. 1993; Liu } \\
\text { et al. 1993; Love et al. } \\
1993\end{array}$ & \\
\hline $\mathrm{TCR} \alpha$ & Mombaerts et al. 1992 & \\
\hline $\mathrm{TCR} \beta$ & Mombaerts et al. 1992 & \\
\hline
\end{tabular}


$\mathrm{CD} 3 \gamma^{-/}$mice showed very few peripheral $\mathrm{T}$ cells (around $10 \%$ of normal values) with low surface TCR and abnormal stoichiometry $(\alpha \beta / \delta \varepsilon \delta \varepsilon \zeta \zeta)$ owing to a severe block at the DN stage (Haks et al. 1998). By contrast, CD3 $\gamma$ deficiency in humans allows the selection of substantial numbers of peripheral $\mathrm{T}$ cells (Recio et al. 2007), which in the case of $\alpha \beta$ T lymphocytes expressed relatively high levels of functional $\alpha \beta T C R$ complexes (Pacheco-Castro et al. 1998), albeit with an abnormal stoichiometry $(\alpha \beta \mathrm{TCR} / \mathrm{CD} 3 \delta \varepsilon \delta \varepsilon \zeta \zeta)$ and an impaired association to CD247 (Zapata et al. 2004). Therefore, the lack of $\mathrm{CD} 3 \gamma$ or $\mathrm{CD} 3 \delta$ during $\alpha \beta$ T-cell development gives rise to inverted phenotypes in mice versus humans, often precluding a meaningful comparison (Siegers et al. 2007).

$\mathrm{CD} 3 \delta$ and $\mathrm{CD} 3 \gamma$ are the most homologous CD3 proteins. Yet, although patients lacking $\mathrm{CD} 3 \delta$ are devoid of mature T cells, CD3 $\gamma$-deficient individuals do have seemingly functional $\alpha \beta$ and $\gamma \delta$ T lymphocytes and generally less severe clinical features (Table 2). These differential phenotypes indicate that in humans CD3 $\delta$ replaces CD3 $\gamma$ in the pre-TCR and TCR for stable expression on and signalling from the cell surface, allowing thymic development of fairly functional $\mathrm{T}$ cells. In support of this notion, expression of a human, but not a mouse, $\mathrm{CD} 3 \delta$ transgene rescued $\alpha \beta$ and $\gamma \delta$ T-cell development in mice that were deficient for both CD3 $\delta$ and CD3 $\gamma$ (Fernández-Malavé et al. 2006; Siegers et al. 2007). Because pre-TCR and $\gamma \delta$ TCR complexes in mice do not seem to incorporate CD3 $\delta$ (Malissen et al. 1999), these data further suggest that CD3 $\delta$ has evolved distinct features in humans that allows it to substitute CD3 $\gamma$ in both species.

$\mathrm{CD} 3 \varepsilon^{-1-}$ mice showed abrogated T-cell development with a severe block at the DN stage (DeJarnette et al. 1998) (Figure 2), supporting a shared critical role on thymocyte development versus humans (de Saint Basile et al. 2004).

As observed in humans, CD247 $7^{-1}$ mice (Liu et al. 1993) showed a partial block at the DP stage with weak transition to SP $\mathrm{T}$ cells and very low surface TCR in both thymocytes and peripheral T cells, which are nonfunctional (Liu et al. 1993).

T-cell development in TCR $\alpha^{-/-}$mice is blocked at the DP stage, indicating that TCR gene rearrangements are critical for $\alpha \beta$ T-cell differentiation, whereas $\gamma \delta$ T cells are unscathed (Mombaerts et al. 1992).

\section{Cellular models}

The complex structure of the TCR and the severe T-cell lymphopenia normally associated to TCRID (Mazariegos et al. 2013) has hampered the dissection of the precise role of each TCR chain for TCR assembly and T-cell selection and function. KO mice, TCRID patients, mutagenized $\mathrm{T}$ cells lacking certain chains, TCR-transfected non- $\mathrm{T}$ cells and, more recently, Knocked-Down (KD) T cells tell different yet complementary tales in each species, as we review here for cellular models.

\section{Human T cells}

\section{Jurkat mutants}

Several variants of the $\alpha \beta$ T-cell leukemia line Jurkat, lacking TCR $\alpha$, TCR $\beta$, or CD3 $\gamma$ have been obtained over the years (Table 7). All lacked surface TCR, thereby supporting the idea that these proteins are required for TCR expression.

In 1992, Geisler described a Jurkat cell line, termed Jurkat Gamma Negative (JGN), deficient for surface TCR expression owing to the lack of CD3 $\gamma$ (Geisler 1992). Using JGN and site-directed mutagenesis, they identified a di-leucine motif in the intracellular (IC) domain of CD3 $\gamma$ implicated in TCR internalization (Dietrich et al. 1996a), two EC interaction sites of $\mathrm{CD} 3 \gamma$ with $\mathrm{CD} 3 \varepsilon$, and one transmembrane (TM) residue involved in binding to TCR $\beta$. They also demonstrated that $\mathrm{N}$-glycosylation in $\mathrm{CD} 3 \gamma$ is not required for TCR assembly and expression, and that the IC domain of CD3 $\gamma$ is not required for surface TCR expression (Dietrich et al. 1996b). Experiments using chimeric constructions of $\mathrm{CD} 3 \gamma$ and $\mathrm{CD} 3 \delta$ demonstrated that the IC and TM regions of these highly homologous proteins were interchangeable (Wegener et al. 1995). TCR $\alpha$ - or TCR $\beta$-deficient Jurkat cell lines have been also used to define important assembly residues in TCR chains, TCR assembly hierarchy, endoplasmic reticulum

Table 7: Jurkat variants.

\begin{tabular}{lll}
\hline Name & \multicolumn{1}{c}{ Lacks } & \multicolumn{1}{c}{ Reference } \\
\hline JGN & CD3 $\gamma$ & Geisler 1992 \\
R3.20.11a & TCR $\alpha$ and TCR $\beta$ & Arnaud et al. 2001 \\
JR3.11 & TCR $\alpha$ & Arnaud et al. 2001 \\
JRT-T3.1 & TCR $\alpha$ & Weiss and Stobo 1984 \\
18.B3 & TCR $\alpha$ & Saito et al. 1987 \\
J76.2 & TCR $\beta$ & Arnaud et al. 2001 \\
JRT3-T3.5 & TCR $\beta$ & Weiss and Stobo 1984 \\
JBN & TCR $\beta$ & Saito et al. 1987 \\
\hline
\end{tabular}


retention of partial complexes, and degradation of TCR chains (Dietrich et al. 1999; Martin et al. 1999; Arnaud et al. 2001).

\section{Knocked-Down (KD) Jurkat}

We have generated Jurkat $\mathrm{KD}$ lines for $\mathrm{CD} 3 \delta$ or CD3 $\gamma$ that show that both chains, although highly homologous, are essential for surface TCR expression (Garcillán, unpublished data). This observation is in agreement with the profound T-specific lymphopenia found in $\mathrm{CD} 3 \delta \mathrm{KO}$ mice and $\mathrm{CD} 3 \delta$-deficient patients, although residual surface TCR was found in T cells from both mutants. However, cellular models do not always recapitulate the human TCRID, as CD3 $\gamma$ deficient patients (but not KO mice) showed abundant $\mathrm{T}$ cells and surface TCR expression (Perez-Aciego et al. 1991), whereas JGN lacked surface TCR. We believe that intrathymic selection pressure can explain this discrepancy, which also shows that human and murine TCR chains have acquired different roles upon speciation (see "Animal models").

\section{Immortalized $T$ cells from TCRID patients}

Both HVS- and HTLV-1-immortalized T-cell lines have been derived from CD3 $\gamma$-deficient patients (Pacheco-Castro et al. 1998; Torres et al. 2003), which preserved the TCR expression features of their donors. These cell lines have been instrumental to show that despite decreased surface TCR expression several mature T-cell responses were normally induced via their mutant TCR, including calcium flux, cytotoxicity, upregulation of $\mathrm{CD} 69$, proliferation, and synthesis of specific cytokines, such as TNF $\alpha$ and IFN $\gamma$. In contrast, TCR-induced IL-2 synthesis, adhesion, tyrosine phosphorylation, and PMA-induced TCR downregulation were impaired (Torres et al. 2002; Torres et al. 2003; Reine et al. 2011).
Cell lines derived from patients with partial CD3 $\delta$ or complete CD247 deficiency have been also generated using allogeneic feeder cells and IL-2 (Gil et al. 2011; Garcillán et al. 2014; Marin, unpublished data). These cell lines also preserved the features of the primary lymphocytes and have been useful for biochemical and functional analyses.

\section{Mouse T cells}

Several murine T-cell lines deficient in one of the TCR chains have been also studied. In 1988, a CD247 deficient cell line (MA5.8) was generated by chemically mutagenesis of the antigen-specific 2B4 T-cell hybridomas (Sussman et al. 1988). MA5.8 cells were able to express small amounts of surface TCR but failed to respond normally to antigens. MA5.8 has been widely used to establish the role of CD247 in TCR assembly (Dietrich et al. 1999; Delgado and Alarcon 2005) and to study CD247 splicing variants present in systemic lupus erythematosus patients (Tsuzaka et al. 2003; Tsuzaka et al. 2005). Later, a CD38-deficient T-cell line was obtained by repetitive subcloning at limiting dilution of the 2B4 T-cell hybridoma line. Studies with this cell line showed that, in the absence of $\mathrm{CD} 3 \delta$, surface TCR expression was abolished and the other TCR chains were retained in the endoplasmic reticulum (Bonifacino et al. 1989). Another study corroborated these results analyzing a murine cytotoxic T lymphocyte (CTL) clone that selectively lacked expression of the CD3 $\delta$ mRNA (Buferne et al. 1992). Lastly, studies in a CTL clone deficient in both $\mathrm{CD} 3 \delta$ and $\mathrm{CD} 3 \gamma$ showed that expression of either $\mathrm{CD} 3 \delta$ or $\mathrm{CD} 3 \gamma$ alone failed to reconstitute surface TCR expression, but reconstitution with cytoplasmically truncated $\mathrm{CD} 3 \delta$ and $\mathrm{CD} 3 \gamma$ led to reexpression of the TCR, demonstrating that both chains are required

Table 8: Cellular models to study the role of CD3 $\gamma$ and CD3 $\delta$ in TCR expression.

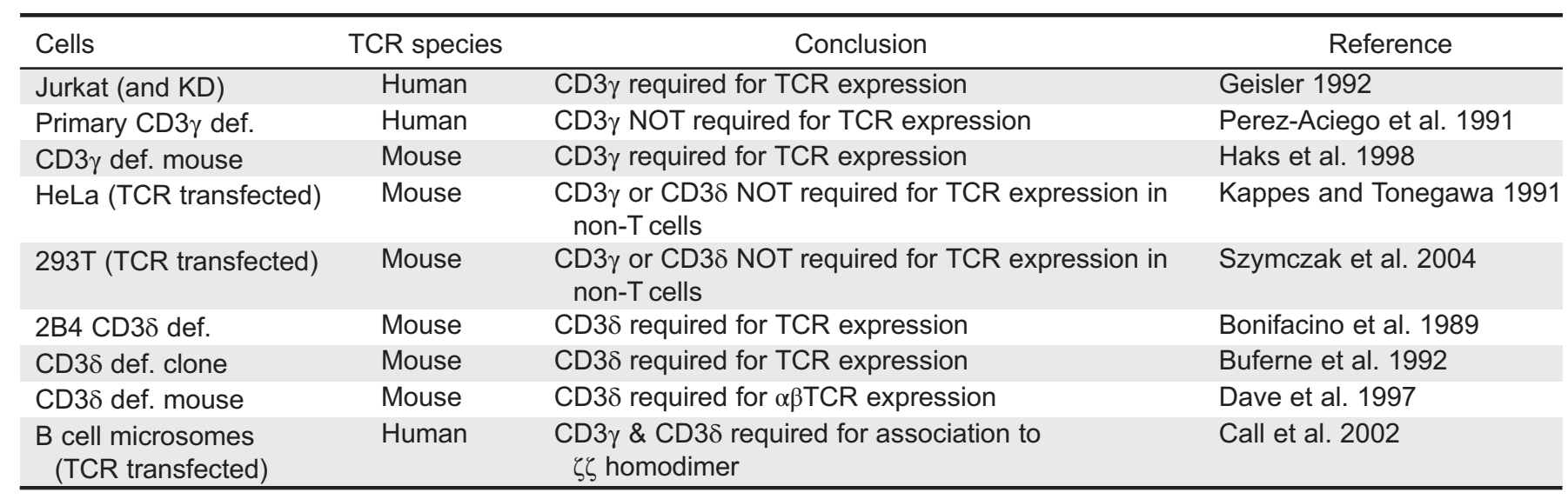


for surface TCR expression, whereas their cytoplasmic domains are dispensable (Luton et al. 1997).

A controversy about the requirement of $\operatorname{CD} 3 \gamma$ or CD38 for TCR assembly and surface expression has been active for years. Several studies using primary cells, cell lines or TCR-transfected non-T cells have led to different conclusions, both for and against their critical role (Table 8 ).

\section{ACKNOWLEDGEMENTS}

We thank all patients for their cooperation and Drs C. Aydogmus and F. Cipe (Pediatric Immunology, Istanbul Kanuni Sultan Süleyman Hospital, Istambul, Turkey), A. Ikinciogullari, S. Haskologlu and F. Dogu (Pediatric Immunology-Allergy, Ankara University School of Medicine, Ankara, Turkey), G. Esteso, M. Valés-Gómez and H.T. Reyburn (Immunology and Oncology, National Centre for Biotechnology CSIC, Madrid, Spain), J. Gil (Immunology, Hospital Gregorio Marañón, Madrid, Spain), O. de la Calle (Immunology, Hospital San Pau, Barcelona, Spain), R. Cedeño (Hospital Oncológico "Dr Julio Villacreses Colmont" Solca Manabi-Esmeraldas, Portoviejo, Manabi, Ecuador), and M. Hönig (Immunologie, Universitätsklinik für Kinder- und Jugendmedizin, Ulm, Germany) for sharing unpublished data.

This work was supported by grants from MINECO (SAF2011-24235 and BES-2012-055054), CAM (S2010/BMD-2316), RIER (RD08-0075-0002) and Lair (2012/0070).

\section{REFERENCES}

Al-Herz, W., Bousfiha, A., Casanova, J.L., Chatila, T., Conley, M.E., Cunningham-Rundles, C., Etzioni, A., Franco, J.L., Gaspar, H.B., Holland, S.M., Klein, C., Nonoyama, S., Ochs, H.D., Oksenhendler, E., Picard, C., Puck, J.M., Sullivan, K., and Tang, M.L. 2014. Primary immunodeficiency diseases: an update on the classification from the international union of immunological societies expert committee for primary immunodeficiency. Front Immunol. 5:162. PMID: 24795713. doi: 10.3389/fimmu.2014.00162.

Allende, L.M., Garcia-Perez, M.A., Moreno, A., RuizContreras, J., and Arnaiz-Villena, A. 2000. Fourteen years' follow-up of an autoimmune patient lacking the CD3 gamma subunit of the T-lymphocyte receptor. Blood. 96(12):4007-4008. PMID: 11186279.
Arnaiz-Villena, A., Perez-Aciego, P., Ballestin, C., Sotelo, T., Perez-Seoane, C., Martin-Villa, J.M., and Regueiro, J.R. 1991. Biochemical basis of a novel T lymphocyte receptor immunodeficiency by immunohistochemistry. A possible CD3 gamma abnormality. Lab Invest. 64(5):675-681. PMID: 1709425.

Arnaiz-Villena, A., Timon, M., Corell, A., Perez-Aciego, P., Martin-Villa, J.M., and Regueiro, J.R. 1992. Brief report: primary immunodeficiency caused by mutations in the gene encoding the CD3-gamma subunit of the T-lymphocyte receptor. N. Engl. J. Med. 327(8): 529-533. PMID: 1635567. doi: 10.1056/nejm 199208 203270805.

Arnaud, J., Erard, M., Martin, E., Llobera, R., Gouaillard, C., Constans, J., and Rubin, B. 2001. Molecular modelling and endoplasmic reticulum retention of mutated TCR/CD3 complexes. Scand. J. Immunol. 53(6):540-552. PMID: 11422902. doi: 10.1046/j. 1365-3083.2001.00906.x.

Bonifacino, J.S., Suzuki, C.K., Lippincott-Schwartz, J., Weissman, A.M., and Klausner, R.D. 1989. Pre-Golgi degradation of newly synthesized T-cell antigen receptor chains: intrinsic sensitivity and the role of subunit assembly. J. Cell Biol. 109(1):73-83. PMID: 2663883. doi: 10.1083/jcb.109.1.73.

Brownlie, R.J., and Zamoyska, R. 2013. T cell receptor signalling networks: branched, diversified and bounded. Nat. Rev. Immunol. 13(4):257-269. PMID: 23524462. doi: 10.1038/nri3403.

Buferne, M., Luton, F., Letourneur, F., Hoeveler, A., Couez, D., Barad, M., Malissen, B., Schmitt-Verhulst, A.M., and Boyer, C. 1992. Role of CD3 delta in surface expression of the TCR/CD3 complex and in activation for killing analyzed with a CD3 delta-negative cytotoxic T lymphocyte variant. J. Immunol. 148(3):657664. PMID: 1530953.

Call, M.E., Pyrdol, J., Wiedmann, M., and Wucherpfennig, K.W. 2002. The organizing principle in the formation of the T Cell Receptor-CD3 complex. Cell. 111:967-979. PMID: 12507424. doi: 10.1016/S00928674(02)01194-7.

Casanova, J.L., Conley, M.E., Seligman, S.J., Abel, L., and Notarangelo, L.D. 2014. Guidelines for genetic studies in single patients: lessons from primary immunodeficiencies. J. Exp. Med. pii: jem20140520.

Chien, Y.H., Meyer, C., and Bonneville, M. 2014. gammadelta T Cells: first line of defense and beyond. Ann. Rev. Immunol. doi: 10.1146/annurev-immunol032713-120216.

Dadi, H., Simon, A.J., and Roifman, C.M. 2003. Effect of CD3d deficiency on maturation of ab and gd T-cell lineages in Severe Combined Immunodeficiency. N. 
Eng. J. Med. 349(19):1821-1828. PMID: 14602880. doi: 10.1056/NEJMoa031178.

Dave, V.P. 2009. Hierarchical role of CD3 chains in thymocyte development. Immunol. Rev. 232(1):2233. PMID: 19909353. doi: 10.1111/j.1600-065X.2009. 00835.x.

Dave, V.P., Cao, Z., Browne, C., Alarcon, B., FernandezMiguel, G., Lafaille, J., de la Hera, A., Tonegawa, S., and Kappes, D.J. 1997. CD3 delta deficiency arrests development of the alpha beta but not the gamma delta $T$ cell lineage. EMBO J. 16(6):1360-1370. PMID: 9135151. doi: 10.1093/emboj/16.6.1360.

de Saint Basile, G., Geissmann, F., Flori, E., Uring-Lambert, B., Soudais, C., Cavazzana-Calvo, M., Durandy, A., Jabado, N., Fischer, A., and Le Deist, F. 2004. Severe combined immunodeficiency caused by deficiency in either the delta or the epsilon subunit of CD3. J. Clin. Invest. 114(10):1512-1517. PMID: 15546002. doi: $10.1172 /$ jci200422588.

DeJarnette, J.B., Sommers, C.L., Huang, K., Woodside, K.J., Emmons, R., Katz, K., Shores, E.W., and Love, P.E. 1998. Specific requirement for CD3epsilon in T cell development. Proc. Natl. Acad. Sci. USA. 95 (25):14909-14914. doi: 10.1073/pnas.95.25.14909.

Delgado, P., and Alarcon, B. 2005. An orderly inactivation of intracellular retention signals controls surface expression of the $\mathrm{T}$ cell antigen receptor. J. Exp. Med. 201(4):555-566. PMID: 15728236. doi: 10.1084/jem.20041133.

Dietrich, J., Hou, X., Wegener, A.M., Pedersen, L.O., Odum, N., and Geisler, C. 1996a. Molecular characterization of the di-leucine-based internalization motif of the T cell receptor. J. Biol. Chem. 271(19):1144111448. PMID: 8626701. doi: 10.1074/jbc.271.19.11441.

Dietrich, J., Kastrup, J., Lauritsen, J.P., Menne, C., von Bulow, F., and Geisler, C. 1999. TCRzeta is transported to and retained in the Golgi apparatus independently of other TCR chains: implications for TCR assembly. Eur. J. Immunol. 29(5):1719-1728. doi: $\quad$ 10.1002/(SICI)1521-4141(199905)29:05<1719:: AID-IMMU1719>3.3.CO;2-D; doi: 10.1002/(SICI) 1521-4141(199905)29:05<1719::AID-IMMU1719>3.0. CO;2-M.

Dietrich, J., Neisig, A., Hou, X., Wegener, A.M., Gajhede, M., and Geisler, C. 1996b. Role of CD3 gamma in T cell receptor assembly. J. Cell Biol. 132(3):299310. PMID: 8636209. doi: 10.1083/jcb.132.3.299.

Fernández-Malavé, E., Wang, N., Pulgar, M., Schamel, W.W., Alarcon, B., and Terhorst, C. 2006. Overlapping functions of human CD3delta and mouse CD3gamma in alphabeta T-cell development revealed in a humanized CD3gamma-mouse. Blood. 108(10):3420
3427. PMID: 16888097. doi: 10.1182/blood-2006-03010850.

Fuehrer, M., Pannicke, U., Schuetz, C., Jacobsen, E.M., Schulz, A., Friedrich, W., Schwarz, K., and Honig, M. 2014. Successful haploidentical hematopoietic stem cell transplantation in a patient with SCID due to CD3epsilon deficiency: need for IgG-substitution 6 years later. Klin. Padiatr. 226(3):149-153. PMID: 24515816. doi: 10.1055/s-0033-1361142.

Garcillán, B., Mazariegos, M.S., Fisch, P., Res, P.C., Muñoz-Ruiz, M., Gil, J., Lopez-Granados, E., Fernandez-Malave, E., and Regueiro, J.R. 2014. Enrichment of the rare $\mathrm{CD} 4+\gamma \delta \mathrm{T}$-cell subset in patients with atypical CD3 $\delta$ deficiency. J. Allergy Clin. Immunol. 133 (4):1205-1208.e9. PMID: 24290291. doi: 10.1016/j. jaci.2013.10.002.

Geisler, C. 1992. Failure to synthesize the CD3-gamma chain. Consequences for $\mathrm{T}$ cell antigen receptor assembly, processing, and expression. J. Immunol. 148(8):2437-2445. PMID: 1532815.

Gil, J., Busto, E.M., Garcillán, B., Chean, C., GarciaRodriguez, M.C., Diaz-Alderete, A., Navarro, J., Reine, J., Mencia, A., Gurbindo, D., Belendez, C., Gordillo, I., Duchniewicz, M., Hohne, K., Garcia-Sanchez, F., Fernandez-Cruz, E., Lopez-Granados, E., Schamel, W.W., Moreno-Pelayo, M.A., Recio, M.J., and Regueiro, J.R. 2011. A leaky mutation in CD3D differentially affects alphabeta and gammadelta $\mathrm{T}$ cells and leads to a Talphabeta-Tgammadelta+B+NK+ human SCID. J. Clin. Invest. 121(10):3872-3876. PMID: 21926461. doi: $10.1172 /$ jci44254.

Gokturk, B., Keles, S., Kirac, M., Artac, H., Tokgoz, H., Guner, S.N., Caliskan, U., Caliskaner, Z., van der Burg, M., van Dongen, J., Morgan, N.V., and Reisli, I. 2014. CD3G gene defects in familial autoimmune thyroiditis. Scand. J. Immunol. doi: 10.1111/sji. 12200.

Haks, M.C., Krimpenfort, P., Borst, J., and Kruisbeek, A. M. 1998. The CD3gamma chain is essential for development of both the TCRalphabeta and TCRgammadelta lineages. Embo. J. 17(7):1871-1882. PMID: 9524111. doi: 10.1093/emboj/17.7.1871.

Hayes, S.M., and Love, P.E. 2006. Stoichiometry of the murine gammadelta T cell receptor. J. Exp. Med. 203(1):47-52. PMID: 16418397. doi: 10.1084/jem. 20051886.

Hirschhorn, R. 2003. In vivo reversion to normal of inherited mutations in humans. J. Med. Genet. 40 (10):721-728. PMID: 14569115. doi: 10.1136/ jmg.40.10.721.

Kappes, D.J., and Tonegawa, S. 1991. Surface expression of alternative forms of the TCR/CD3 complex. Proc. 
Natl. Acad. Sci. USA. 88(23):10619-10623. doi: 10.1073/ pnas.88.23.10619.

Kuhns, M.S., and Davis, M.M. 2012. TCR signaling emerges from the sum of many parts. Front Immunol. 3:159. PMID: 22737151. doi: 10.3389/fimmu.2012. 00159.

Le Deist, F., Thoenes, G., Corado, J., Lisowska-Grospierre, B., and Fischer, A. 1991. Immunodeficiency with low expression of the T cell receptor/CD3 complex. Effect on T lymphocyte activation. Eur. J. Immunol. 21(7):1641-1647. PMID: 1676369. doi: 10.1002/ eji.1830210709.

Liu, C.P., Ueda, R., She, J., Sancho, J., Wang, B., Weddell, G., Loring, J., Kurahara, C., Dudley, E.C., Hayday, A., Terhorst, C., and Huang, M. 1993. Abnormal T cell development in CD3-zeta-/- mutant mice and identification of a novel $\mathrm{T}$ cell population in the intestine. EMBO J. 12(12):4863-4875. PMID: 8223495.

Love, P.E., and Hayes, S.M. 2010. ITAM-mediated signaling by the T-cell antigen receptor. Cold Spring Harb. Perspect. Biol. 2(6):a002485. PMID: 20516133. doi: 10.1101/cshperspect.a002485.

Love, P.E., Shores, E.W., Johnson, M.D., Tremblay, M.L., Lee, E.J., Grinberg, A., Huang, S.P., Singer, A., and Westphal, H. 1993. T cell development in mice that lack the zeta chain of the $\mathrm{T}$ cell antigen receptor complex. Science. 261(5123):918-921. PMID: 7688481. doi: 10.1126/science.7688481.

Luton, F., Buferne, M., Legendre, V., Chauvet, E., Boyer, C., and Schmitt-Verhulst, A.M. 1997. Role of CD3gamma and CD3delta cytoplasmic domains in cytolytic T lymphocyte functions and TCR/CD3 down-modulation. J. Immunol. 158(9):4162-4170. PMID: 9126976.

Malissen, B., Ardouin, L., Lyn, S.Y., Guillet, A., and Malissen, M. 1999. Function of the CD3 subunits of the pre-TCR and TCR complexes during T cell development. Adv. Immunol. 72:103-148. PMID: 10361573. doi: 10.1016/S0065-2776(08)60018-8.

Malissen, M., Gillet, A., Ardouin, L., Bouvier, G., Trucy, J., Ferrier, P., Vivier, E., and Malissen, B. 1995. Altered $\mathrm{T}$ cell development in mice with a targeted mutation of the CD3-epsilon gene. Embo J. 14(19):4641-4653. PMID: 7588594.

Malissen, M., Gillet, A., Rocha, B., Trucy, J., Vivier, E., Boyer, C., Kontgen, F., Brun, N., Mazza, G., Spanopoulou, E., Guy-Grand, D., and Malissen, B. 1993. T cell development in mice lacking the CD3-zeta/eta gene. EMBO J. 12(11):4347-4355. PMID: 8223444.

Marcus, N., Takada, H., Law, J., Cowan, M.J., Gil, J., Regueiro, J.R., Plaza Lopez de Sabando, D., LopezGranados, E., Dalal, J., Friedrich, W., Manfred, H.,
Hanson, I.C., Grunebaum, E., Shearer, W.T., and Roifman, C.M. 2011. Hematopoietic stem cell transplantation for CD3delta deficiency. J. Allergy Clin. Immunol. 128(5):1050-1057. PMID: 21757226. doi: 10.1016/j.jaci.2011.05.031.

Martin, E.P., Arnaud, J., Alibaud, L., Gouaillard, C., Llobera, R., Huchenq-Champagne, A., and Rubin, B. 1999. Molecular mechanisms in the TCR (TCR alpha beta-CD3 delta epsilon, gamma epsilon) interaction with zeta 2 homodimers: clues from a 'phenotypic revertant' clone. Int. Immunol. 11(7):1005-1015. PMID: 10383932.

Mazariegos, M.S., Muñoz-Ruiz, M., Reiné, J., Garcillán, B., Recio, M.J., Fernández-Malavé, E., and Regueiro, J.R. 2013. Inmunodeficiencias congénitas del receptor de antígeno de los linfocitos T. Inmunología. 32 (3):94-101. doi: 10.1016/j.inmuno.2013.04.002.

Mombaerts, P., Clarke, A.R., Rudnicki, M.A., Iacomini, J., Itohara, S., Lafaille, J.J., Wang, L., Ichikawa, Y., Jaenisch, R., Hooper, M.L., and Tonegawa, S. 1992. Mutations in T-cell antigen receptor genes alpha and beta block thymocyte development at different stages. Nature. 360(6401):225-231. PMID: 1359428. doi: $10.1038 / 360225 \mathrm{a} 0$.

Morgan, N.V., Goddard, S., Cardno, T.S., McDonald, D., Rahman, F., Barge, D., Ciupek, A., Straatman-Iwanowska, A., Pasha, S., Guckian, M., Anderson, G., Huissoon, A., Cant, A., Tate, W.P., Hambleton, S., and Maher, E.R. 2011. Mutation in the TCRalpha subunit constant gene (TRAC) leads to a human immunodeficiency disorder characterized by a lack of TCRalphabeta+ T cells. J. Clin. Invest. 121(2):695702. PMID: 21206088. doi: 10.1172/JCI41931.

Muñoz-Ruiz, M., Perez-Flores, V., Garcillán, B., Guardo, A.C., Mazariegos, M.S., Takada, H., Allende, L.M., Kilic, S.S., Sanal, O., Roifman, C.M., LopezGranados, E., Recio, M.J., Martinez-Naves, E., Fernandez-Malave, E., and Regueiro, J.R. 2013. Human $\mathrm{CD} 3 \gamma$, but not $\mathrm{CD} 3 \delta$, haploinsufficiency differentially impairs $\gamma \delta$ versus $\alpha \beta$ surface TCR expression. BMC Immunol. 14(1):3. PMID: 23336327. doi: 10.1186/ 1471-2172-14-3.

Ozgur, T.T., Asal, G.T., Cetinkaya, D., Orhan, D., Kilic, S.S., Usta, Y., Ozen, H., and Tezcan, I. 2008. Hematopoietic stem cell transplantation in a CD3 gammadeficient infant with inflammatory bowel disease. Pediatr. Transpl. 12(8):910-913. PMID: 18482219. doi: 10.1111/j.1399-3046.2008.00957.x.

Pacheco-Castro, A., Alvarez-Zapata, D., Serrano-Torres, P., and Regueiro, J.R. 1998. Signaling through a CD3 gamma-deficient TCR/CD3 complex in immortalized 
mature CD4+ and CD8+ T lymphocytes. J. Immunol. 161(6):3152-3160. PMID: 9743383.

Perez-Aciego, P., Alarcon, B., Arnaiz-Villena, A., Terhorst, C., Timon, M., Segurado, O.G., and Regueiro, J.R. 1991. Expression and function of a variant $T$ Cell Receptor complex lacking CD3g. J. Exp. Med. 174:319-326. PMID: 1713248.

Piirilä, H., Väliaho, J., and Vihinen, M. 2006. Available from http://structure.bmc.lu.se/idbase.

Recio, M.J., Moreno-Pelayo, M.A., Kilic, S.S., Guardo, A. C., Sanal, O., Allende, L.M., Perez-Flores, V., Mencia, A., Modamio-Hoybjor, S., Seoane, E., and Regueiro, J. R. 2007. Differential biological role of CD3 chains revealed by human immunodeficiencies. J. Immunol. USA: 2556-2564. PMID: 17277165.

Regueiro, J.R., Arnaiz-Villena, A., Ortiz de Landazuri, M., Martin Villa, J.M., Vicario, J.L., Pascual-Ruiz, V., Guerra-Garcia, F., Alcami, J., Lopez-Botet, M., and Manzanares, J. 1986. Familial defect of CD3 (T3) expression by $\mathrm{T}$ cells associated with rare gut epithelial cell autoantibodies. Lancet. 1(8492):1274-1275. doi: 10.1016/S0140-6736(86)91413-3.

Reine, J., Busto, E.M., Muñoz-Ruiz, M., Rossi, N.E., Rodriguez-Fernandez, J.L., Martinez-Naves, E., Regueiro, J.R., and Recio, M.J. 2011. CD3gamma-independent pathways in TCR-mediated signaling in mature $\mathrm{T}$ and iNKT lymphocytes. Cell Immunol. 271(1):62-66. PMID: 21764047. doi: 10.1016/j. cellimm.2011.06.009.

Rieux-Laucat, F., Hivroz, C., Lim, A., Mateo, V., Pellier, I., Selz, F., Fischer, A., and Le Deist, F. 2006. Inherited and somatic CD3zeta mutations in a patient with $\mathrm{T}$ cell deficiency. N. Engl. J. Med. 354(18):1913-1921. PMID: 16672702. doi: 10.1056/NEJMoa053750.

Roberts, J.L., Lauritsen, J.P., Cooney, M., Parrott, R.E., Sajaroff, E.O., Win, C.M., Keller, M.D., Carpenter, J. H., Carabana, J., Krangel, M.S., Sarzotti, M., Zhong, X.P., Wiest, D.L., and Buckley, R.H. 2007. T-B+NK+ severe combined immunodeficiency caused by complete deficiency of the CD3zeta subunit of the T-cell antigen receptor complex. Blood. 109(8):3198-3206. PMID: 17170122. doi: 10.1182/blood-2006-08043166.

Saito, T., Weiss, A., Miller, J., Norcross, M.A., and Germain, R.N. 1987. Specific antigen-Ia activation of transfected human $\mathrm{T}$ cells expressing murine $\mathrm{Ti}$ alpha beta-human T3 receptor complexes. Nature. 325 (7000):125-130. PMID: 3027582. doi: 10.1038/32 $5125 \mathrm{a} 0$.

Sanal, O., Yel, L., Ersoy, F., Tezcan, I., and Berkel, A.I. 1996. Low expression of T-cell receptor-CD3 complex: a case with a clinical presentation resembling humoral immunodeficiency. Turk. J. Pediatr. 38(1): 81-84. PMID: 8819625.

Sarantopoulos, S., Stevenson, K.E., Kim, H.T., Cutler, C. S., Bhuiya, N.S., Schowalter, M., Ho, V.T., Alyea, E.P., Koreth, J., Blazar, B.R., Soiffer, R.J., Antin, J.H., and Ritz, J. 2009. Altered B-cell homeostasis and excess BAFF in human chronic graft-versus-host disease. Blood. 113(16):3865-3874. PMID: 19168788. doi: 10.1182/blood-2008-09-177840.

Siegers, G.M., Swamy, M., Fernandez-Malave, E., Minguet, S., Rathmann, S., Guardo, A.C., Perez-Flores, V., Regueiro, J.R., Alarcon, B., Fisch, P., and Schamel, W.W. 2007. Different composition of the human and the mouse gammadelta $\mathrm{T}$ cell receptor explains different phenotypes of CD3gamma and CD3delta immunodeficiencies. J. Exp. Med. USA: 2537-2544.

Soudais, C., de Villartay, J.P., Le Deist, F., Fischer, A., and Lisowska-Grospierre, B. 1993. Independent mutations of the human CD3-epsilon gene resulting in a $\mathrm{T}$ cell receptor/CD3 complex immunodeficiency. Nat. Genet. 3(1):77-81. PMID: 8490660. doi: 10.1038/ ng0193-77.

Sussman, J.J., Bonifacino, J.S., Lippincott-Schwartz, J., Weissman, A.M., Saito, T., Klausner, R.D., and Ashwell, J.D. 1988. Failure to synthesize the T cell CD3zeta chain: structure and function of a partial $\mathrm{T}$ cell receptor complex. Cell. 52(1):85-95. PMID: 3278811. doi: 10.1016/0092-8674(88)90533-8.

Szymczak, A.L., Workman, C.J., Wang, Y., Vignali, K. M., Dilioglou, S., Vanin, E.F., and Vignali, D.A. 2004. Correction of multi-gene deficiency in vivo using a single 'self-cleaving' $2 \mathrm{~A}$ peptide-based retroviral vector. Nat. Biotechnol. 22(5):589-594. PMID: 15064769. doi: 10.1038/nbt957.

Takada, H., Nomura, A., Roifman, C.M., and Hara, T. 2005. Severe combined immunodeficiency caused by a splicing abnormality of the CD3delta gene. Eur. J. Pediatr. 164(5):311-314. PMID: 15729559. doi: 10.1007/s00431-005-1639-6.

Thoenes, G., Soudais, C., le Deist, F., Griscelli, C., Fischer, A., and Lisowska-Grospierre, B. 1992. Structural analysis of low TCR-CD3 complex expression in $\mathrm{T}$ cells of an immunodeficient patient. J. Biol. Chem. 267(1):487-493. PMID: 1370449.

Tokgoz, H., Caliskan, U., Keles, S., Reisli, I., Guiu, I.S., and Morgan, N.V. 2013. Variable presentation of primary immune deficiency: two cases with CD3 gamma deficiency presenting with only autoimmunity. Pediatr. Allergy Immunol. 24(3):257-262. PMID: 23590417. doi: 10.1111/pai.12063.

Torres, P.S., Alcover, A., Zapata, D.A., Arnaud, J., Pacheco, A., Martin-Fernandez, J.M., Villasevil, E.M., 
Sanal, O., and Regueiro, J.R. 2003. TCR dynamics in human mature $\mathrm{T}$ lymphocytes lacking CD3 gamma. J. Immunol. 170(12):5947-5955. PMID: 12794121. doi: 10.4049/jimmunol.170.12.5947.

Torres, P.S., Zapata, D.A., Pacheco-Castro, A., Rodriguez-Fernandez, J.L., Cabanas, C., and Regueiro, J.R. 2002. Contribution of CD3 gamma to TCR regulation and signaling in human mature $\mathrm{T}$ lymphocytes. Int. Immunol. 14(11):1357-1367. PMID: 12407027. doi: 10.1093/intimm/dxf095.

Tsuzaka, K., Fukuhara, I., Setoyama, Y., Yoshimoto, K., Suzuki, K., Abe, T., and Takeuchi, T. 2003. TCR zeta mRNA with an alternatively spliced 3'-untranslated region detected in systemic lupus erythematosus patients leads to the down-regulation of TCR zeta and TCR/CD3 complex. J. Immunol. 171(5):2496-2503. PMID: 12928398. doi: 10.4049/jimmunol.171.5.2496.

Tsuzaka, K., Setoyama, Y., Yoshimoto, K., Shiraishi, K., Suzuki, K., Abe, T., and Takeuchi, T. 2005. A splice variant of the TCR zeta mRNA lacking exon 7 leads to the down-regulation of TCR zeta, the TCR/CD3 complex, and IL-2 production in systemic lupus erythematosus T cells. J. Immunol. 174(6):3518-3525. PMID: 15749888. doi: 10.4049/jimmunol.174.6.3518.

Wada, T., and Candotti, F. 2008. Somatic mosaicism in primary immune deficiencies. Curr. Opin. Allergy
Clin. Immunol. 8(6):510-514. PMID: 18978464. doi: 10.1097/ACI.0b013e328314b651.

Wang, Y., Becker, D., Vass, T., White, J., Marrack, P., and Kappler, J.W. 2009. A conserved CXXC motif in CD3epsilon is critical for $\mathrm{T}$ cell development and TCR signaling. PLoS Biol. 7(12):e1000253. PMID: 19956738. doi: 10.1371/journal.pbio.1000253.

Wegener, A.M., Hou, X., Dietrich, J., and Geisler, C. 1995. Distinct domains of the CD3-gamma chain are involved in surface expression and function of the T cell antigen receptor. J. Biol. Chem. 270(9):46754680. PMID: 7533164. doi: 10.1074/jbc.270.9.4675.

Weiss, A., and Stobo, J.D. 1984. Requirement for the coexpression of $\mathrm{T} 3$ and the $\mathrm{T}$ cell antigen receptor on a malignant human T cell line. J. Exp. Med. 160(5): 1284-1299. PMID: 6208306. doi: 10.1084/jem.160. 5.1284 .

Zapata, D.A., Schamel, W.W., Torres, P.S., Alarcon, B., Rossi, N.E., Navarro, M.N., Toribio, M.L., and Regueiro, J.R. 2004. Biochemical differences in the alphabeta $\mathrm{T}$ cell receptor.CD3 surface complex between $\mathrm{CD} 8+$ and $\mathrm{CD} 4+$ human mature $\mathrm{T}$ lymphocytes. J. Biol. Chem. 279(23):24485-24492. PMID: 15060077. doi: 10.1074/jbc.M311455200. 